\title{
Humor og ironi i tværsproglige og tværkulturelle møder. Bona-fide, ikke-bona-fide og bona-fide-cum-humor sprog- handlinger i dansk og fransk
}

\author{
Lita Lundquist
}

Artiklen tager udgangspunkt i en empirisk undersøgelse af hvordan danskere og franskmænd anvender og reagerer på humor og ironi i professionelle sammenhænge. Humor er i sig selv et mangefacetteret fænomen der er beskrevet i flere sproglige og ikke sproglige discipliner, men når humor studeres som et tværsprogligt og tværkulturelt fænomen, inddrages endnu flere aspekter der kalder på andre former for belysning. Humor betragtes her først som en ikke-bona-fide sproghandling der for at være vellykket via sin semantiske og pragmatiske dobbelt(tydig) hed skal tolkes som en bona-fide-cum-humor sproghandling. Danskeres udbredte anvendelse af humor og (selv)ironi, også i faglige sammenhænge, i modsætning til franskmænds præference for ordspil, forklares sprogligt via særegenheder i det danske overfor det franske sprog, og kulturantropologisk og sociologisk via forskelle i civilisationsprocesser og ledelsesstrukturer i de to kulturer. Artiklen er således et forsøg på at slå bro mellem komparativ sprogforskning og sammenlignende lande- og kulturstudier.

\section{Bona-fide og ikke bona-fide sproghandlinger}

De fleste sproghandlinger hviler på et sæt af konstituerende regler som indeholder reglen om sandhed (Searle 1979), ligesom sandhed indgår i de generelle samtalenormers kvalitetsmaksime (Grice 1967) og i den kommunikative pragmatiks gyldighedskrav om sandhed, rigtighed og oprigtighed (Habermas 1981). Kravet om sandhed gælder først og fremmest den konstative sproghandling, men også i den ekspressive og regulative sproghandling indgår et krav om en vis sandhedsrelation til verden (Searle 1977) ${ }^{1}$.

Andre sproghandlinger er netop defineret ved deres brud på sandhedskravet. Det gælder anvendelsen af metaforer (Ricoeur 1978; 
Searle 1979) og fiktion i tekster (Lundquist 1982), hvor sandhedskravet er suspenderet og det gælder humor og ironi, der netop er blevet karakteriseret som ikke-bona-fide sproghandlinger (Raskin 1985).

Målet med denne artikel er at belyse hvordan en vellykket tolkning af humor og ironi fra bona-fide, over ikke-bona-fide til bona-fide-cum-humor sproghandling afhænger af sprog og kulturel kontekst. Udgangspunktet er en empirisk undersøgelse af danskeres og franskmænds reaktion på hinandens anvendelse af spontan verbal humor $\mathrm{i}$ fælles arbejdssituationer (Lundquist 2009). I undersøgelsen indgår der to forskellige $\operatorname{sprog}^{2}$, dansk og fransk som parternes modersmål, hvilket leder mod en komparativ analyse af de to sprog. De kommunikerende parter befinder sig i en fælles umiddelbar kontekst, der dog fordi den er tværsproglig og tværkulturel, rækker ud i en bredere kontekst, hvor der gælder forskellige kulturelle normer for kommunikativ adfærd i almindelighed og for professionel adfærd i særdeleshed.

Artiklen bevæger sig fra en lingvistisk - først og fremmest semantisk og pragmatisk - beskrivelse af fænomenet sproglig humor og ironi, over en sprogtypologisk sammenligning af anvendelsen af humor og ironi i dansk og fransk, til en kulturel og sociologisk perspektivering der inddrager visse organisations- og ledelsesteoretiske aspekter.

\section{Humor og ironi: semantisk dobbelthed og pragmatisk dobbelt- tydighed}

I næsten alle behandlinger af humor indgår dobbeltheden-i den sproglige form og i det kognitive indhold - og dermed dobbelttydigheden i den pragmatiske fortolkning som definitionskriterium. Den pragmatiske dobbelttydighed består netop $i$ at afkode om en given ytring er intenderet som værende en bona-fide sproghandling, eller som ikke-bona-fide og i sidste instans som en bona-fide-cum-humor sproghandling i form af ordspil, vittighed eller ironi.

\subsection{Den sproglige dobbelthed}

Dobbeltheden i den sproglige form kommer klart til udtryk i Freuds analyse af 'teknikken' i den sproglige vits. Ud fra det efterhånden klassiske eksempel i (1), viser Freud hvordan vitsens effekt opstår af koncentrationen i en sproglig kortform eller "kortslutning" mellem to ord.

(1) "(..) Ich sass neben Salomon Rotschild und er behandelte mich ganz wie seinesgleichen, ganz famillionär" (Freud 1981:13). 
Freud illustrerer vitsens teknik i formlen nedenfor (1a), hvor vi ser hvordan 'familionær' er dannet som en kondensering af to ord ('familiær' og 'millionær') hvilket i Freuds terminologi efterlader sporet af et substitut, der svarer til den latente betydning, der kunne gå i retning af: "Rotschild behandlede mig på en måde der kunne synes familiær, men som alligevel indeholdt et element af millionærens overlegenhed".

$\begin{array}{lll}\text { Famili } & & \text { är } \\ \text { Mili } & o & \text { när } \\ \text { Famili } & \text { o } & \text { när }\end{array}$

Kortformen udløser effekten - smilet og latteren - ifølge Freud fordi "den lystfølelse man opnår på denne måde, svarer til den psykiske anstrengelse man sparer" (Freud 1994:108). Vitsen fører til en umiskendelig glæde ved at føre os fra én forestillingskreds til en anden og fjernere, og lystfølelsen synes at blive større jo mere fremmede de to forestillingsverdener der bliver sammenkoblet af det ene ord, er. Det ene ord sparer os således for en stor mental omvej (Freud 1994:110-111). Den psykologiske forklaring er ifølge Freud at leg med ord og tanker består i at omgå indre censur i form af den kritiske fornufts kontrol (Freud 1994:116) og den ydre censur i form af forskellige magtpositioner (Freud 1994:107).

Vitser, forstået som ordspil som i (1), viste sig i min unders $\varnothing$ gelse beskrevet nedenfor at være den foretrukne form for humor blandt de interviewede franskmænd. Det er da også en form der ses meget hyppigt i fransk litteratur og medier, i almen konversation, ligesom det er en sproglig form der er blevet udførligt teoretisk behandlet i detaillerede stilistikker (fx Guiraud 1976). Her følger to aktuelle eksempler på ordspil fra de franske medier. Det første, "Galeries Lafaillite" ("Galleri Fallitten”), blev hørt på fransk radio (november 2000) under den truende økonomiske krise. Udtrykket spiller på navnet - og den kulturelle reference til - det franske stormagasin Galeries Lafayette. Sprogligt er ordspillet meget økonomisk og elegant idet det med substitution af ét minimalt fonetisk par, [e] overfor [i],

$$
\begin{array}{ll}
\text { Galeries Lafayette } & \text { [fa-jet }] \\
\text { Galeries Lafaillite } & {[\mathrm{fa}-\mathrm{jit}]}
\end{array}
$$

sammenbringer to begreber 1) stormagasinet og 2) fallit. Det er blandingen af de to begreber der skaber den nye latente mening: Galleri 


\section{Lita Lundquist}

Lafayette er på randen af fallit, hvilket - trods den humoristiske effekt der udløses af kortformen - jo ikke er sjovt i sig selv.

Det andet eksempel stammer fra det franske satiriske blad, Le Canard enchaîné ("Den lænkede And"), der udkommer en gang om ugen. Der stod (4. Juni 2008) 'les partenaires soucieux', der er en blanding af de to udtryk 'les partenaires sociaux' (fast udtryk for 'arbejdsmarkedsparter') og 'soucieux' (der betyder 'bekymrede'). Også her ser vi en yderst $\emptyset$ konomisk sproglig teknik, idet ordspillet består i udvekslingen af blot to minimale fonetiske par:

$$
\begin{array}{ll}
\text { les partenaires soucieux } & {[\text { susjø] }} \\
\text { les partenaires sociaux } & {[\text { sosjo] }}
\end{array}
$$

Semantisk er effekten af ordspillet imidlertid enorm, idet et fast socio-politisk fagudtryk forvandles til et værdiladet og argumentativt, alt mens der udløses en humoristisk effekt pga. af den elegante kortform, hvormed der siges meget med få (to) ord.

\subsection{Den kognitive dobbelthed}

I den kognitivt orienterede lingvistik ser man elementer fra Freuds beskrivelse af humor overført i teorier om 'blending' af mentale rum ${ }^{3}$ (Fauconnier 1994; Fauconnier 1999) eller 'mapping' af scripts, hvilket sidste netop er udgangspunktet i den såkaldte Semantic Script-based Theory of Humor (SSTH) (Raskin 1985). Denne teori indskriver sig i rækken af 'incongruity' teorier, der forklarer grundstrukturen i humor som værende en form for uforenelighed. Raskin (1985) beskriver således strukturen i en 'humorous act' som værende "the simultaneous perception of two different things", "a funny reconciliation of two irreconcilables". Dette udgør hypotesen for hans teori om specielt vittighedens grundstruktur og funktionsmåde.

A text can be characterized as a single-joke-carrying text if both of the (following) conditions (...) are satisfied:

i. The text is compatible, fully or in part, with two different scripts

ii. The two scripts with which the text is compatible are opposite (...) (Raskin 1985:99)

Raskin viser med eksemplet nedenfor (Raskin 1985:105) hvordan en joke hviler på at to scripts afløser hinanden: 


\section{Humor og ironi ...}

\footnotetext{
"Er lægen hjemme?", spurgte patienten med hæs hvisken. "Nej", hviskede lægens unge, smukke kone. "Kom bare ind."
}

Det er klart at det er "the oppositeness (which) creates the joke" (Raskin 1985:100), og triggeren er sidste replik "Kom bare ind", der skifter situationen fra læge-script til elsker-script. Der har dog allerede i første del, hvor vi befinder os i lægescriptet, været signaler der også er forenelige med elsker-scriptet, nemlig den megen (hæse) hvisken.

Dobbeltheden fra den leksikalsk-fonetiske analyse af vitsen hos Freud går altså igen i Raskins og senere semantiske beskrivelser (Attardo 1994) af humor, en dobbelthed der naturligvis på det pragmatiske niveau må give sig udslag i en dobbelttydighed med hensyn til den korrekte tolkning.

\subsection{Den pragmatiske dobbelttydighed}

I både ordspillet og vittigheden (der begge omfattes af Freuds 'vits'), og også i ironien som vi skal se senere, er der en dobbelttydighed i den forstand at modtager skal kunne udlede af det sagte at forfatters intention ikke skal tolkes som en bona fide sproghandling ("the no lying, no acting, no joking mode" som er den normale informationsformidlende modus (Raskin 1985)), men som en ikke-bona-fide sproghandling, dvs. som en ikke 'i god tro' handling, dog heller ikke som en 'i ond tro' handling, men som en humoristisk (sprog)handling, dvs. en bona-fidecum-humor sproghandling. I ytringen i (1) "Rotschild behandlede mig familionært" skal modtager f.eks. være villig til at acceptere ordet 'familionært' der strengt taget ikke er et ord (på dansk, tysk, engelsk, osv.). I stedet for at forkaste ytringen som meningsløs fordi et af ordene ikke er i overensstemmelse med det pågældende sprogs normer, skal modtager søge efter en anden betydning, hvilket helst skal ske automatisk og uden for meget supplerende inferensarbejde. Jo hurtigere den korrekte tolkning går, jo mere psykisk energi sparer man ifølge Freud, og jo større bliver den humoristiske effekt. I tværsproglige og tværkulturelle interaktioner, som dem der indgår i mit empiriske materiale, kan der være barrierer for den humoristiske sproghandlings vellykkethed hvis modtager ikke råder over den tilstrækkelige sproglige kompetence til at afkode ord og ytringer som værende ikke-bona-fide sproghandlinger. Omvendt har det vist sig at ordspil, som afsender på et fremmedsprog uforvarende kan komme til at lave i form af lapsus linguae, kan have 


\section{Lita Lundquist}

stor humoristisk og positiv effekt i interaktionen (se 3.2.1). Som Raskin skriver om sådanne "language distortions" hos fremmedsprogede, så er "their ignorance (...) pardonable because it is foreign languages that they are not proficient in" (Raskin 1985). Et eklatant eksempel herpå følger i 3.2.1.

I vittigheder, som i eksempel (4) ovenfor, er historien irrelevant og uden pointe hvis man ikke finder 'triggeren' og kombinerer de to scripts $i$ et modsætningsforhold. Her er det maksimet om relevans der guider modtageren i udredningen af dobbelttydigheden.

I tværsproglig og -kulturel kommunikation kan den humoristiske sproghandling mislykkes fordi afsender og modtager ikke nødvendigvis råder over de samme scripts. I eksempel (4) er læge- og elskerscriptsene så generelle, i europæisk kultur i det mindste, at den humoristiske handling er dømt til at lykkes, mens eksempel (2) der refererer til et konkret stormagasin med stor kulturel betydning i franskmænds bevidsthed viser at scripts kan være kulturelt bestemte og derfor udgøre en hindring for den humoristiske sproghandlings vellykkethed blandt ikke franskmænd. Kulturbundne scripts er medvirkende årsag til at latter "so often balks away at national frontiers" (Raskin 1985:17.)

Også ironi kan beskrives ved hjælp af dobbelthed, nemlig som en fortolkning af "anden grad", hvor fortolkningen fordobles ved at afsenders udsagn skal afkodes som en fortolkning (af første grad) af en anden persons stemme (Sperber \& Wilson 1995:238). Denne "ekkoeffekt" ("echoing") kræver som afkodning at modtager tolker såvel den citerede stemme som afsenders holdning til denne. Ironi er kendetegnet ved at denne holdning er implicit og altid af negativ og afstandtagende art:

The attitude expressed by an ironical utterance is invariably of the rejecting or disapproving kind. The speaker dissociates herself from the opinion echoed and indicates that she does not hold it herself (Sperber \& Wilson 1995:239).

\subsection{Opsamling på humorens dobbelt(tydig)hed}

Anvendelse af humor - i form af ordspil, vittigheder, ironi m.m. - kan beskrives som en speciel form for ikke-bona-fide sproghandling, idet fortolkningen ikke stopper her, men bør gå et skridt videre til fortolkningen af ytringen som værende en bona-fide-cum-humor sproghandling (Raskin 1985:104). Raskin går så vidt som til at sige at "Humor seems to be the next most socially accepted form of communication 
in our society after bona-fide communication" (Raskin 1985:104), et synspunkt der skal vise sig at være både sprog- og kulturafhængigt. Ikke desto mindre var det bona-fide-cum-humor- sproghandlingen der var udgangspunkt for den undersøgelse der beskrives nedenfor. Mere præcist var min hypotese at humor kunne virke som positiv mediator (Latour 2005) i tværsproglige og -kulturelle professionelle interaktioner, fordi humor kan bidrage til at danne nye sociale bånd i form af "momentary associations (...) characterized by the way (they) gather into new shapes" (Latour 2005:65) i relationer som normalt er præget af informationsmættet, strategisk bona fide kommunikation.

\section{Humor og ironi i dansk-franske arbejdssituationer}

En tidligere undersøgelse af hvordan danskere og franskmænd anvender og reagerer på hinandens anvendelse af spontan verbal humor i professionelle kommunikationssituationer, viste at de forstår og tolker humor og ironi vidt forskelligt. Unders $\varnothing$ gelsen, der bestod af interviews foretaget med fem danskere der arbejder i Frankrig og med fem franskmænd der arbejder i Danmark, viste for det første at franskmænd generelt ikke anvender humor og slet ikke ironi på arbejdspladsen, hvor danskere hyppigt anvender begge dele i både privatsfæren og på arbejdspladsen (Lundquist 2009). Det fremgik også af interviewene at franskmænd generelt foretrækker humor i form af ordspil, mens danskere ikke går af vejen for at anvende ironi, ikke mindst selvironi.

\subsection{Dansk ironi som mislykket ikke-bona-fide sproghandling over for franskmoend}

Alle danskere uden undtagelse og fire af de fem franskmænd gav som svar på spørgsmålet "er der forskel på danskeres og franskmænds anvendelse af humor i arbejdssituationer?" at danskerne bruger meget ironi, til stor overraskelse for franskmændene, der selv ville afholde sig fra denne form for humor på arbejdspladsen, og for $\emptyset$ vrigt slet ikke fandt denne form for ikke-bona-fide sproghandling særlig morsom ${ }^{4}$. En af de interviewede franskmænd nævnte gang på gang at han i halvdelen af tilfældene var i vildrede om hvorvidt der var tale om humor eller ej, og at denne usikkerhed var ved at gøre ham paranoid: "Nu, når nogen fortæller en joke, så har jeg tendens til først at tolke det som ikke værende en joke, og så, når jeg begynder at tænke nærmere efter, så siger jeg til mig selv, lad nu være med at overdrive, det var formodentlig bare for sjov"5. Denne bemærkning er interessant fordi den viser at den af Freud omtalte "økonomisering af psykisk energi" der er nødvendig for at 


\section{Lita Lundquist}

vitsen lykkes, dvs. udløser lystfølelse, ikke finder sted, når modtageren skal bruge flere inferentielle etaper og overvejelser, før han når frem over den formodentlig intenderede ikke-bona-fide kommunikation til en bona-fide-cum-humor kommunikation. Faktisk erstattes lystfølelsen af ubehag og paranoia.

\subsubsection{Eksempel og sproglig beskrivelse}

Ovennævnte interviewperson nævnte bl.a. følgende oplevelse fra sin arbejdsplads, der havde såret ham dybt. En dansk kollega spurgte ham hvornår han ville forbedre sit danske sprog, hvortil vores interviewperson forklarede at han havde vanskeligheder med at få plads på et danskkursus. Så siger den danske kollega, på engelsk, refereret i interviewet på fransk med denne ordlyd:

(5) De toutes façons, pour apprendre le danois, écoute, il n'y a pas le choix, il faut que tu divorces et épouses une Danoise.

Dette betyder direkte og ordret oversat til dansk:

(5a) Hvorom alt er, for at lære dansk, så er der ikke noget valg, du må lade dig skille og gifte dig med en dansk kvinde.

Problemet med at foretage en sproglig analyse af denne ytring er at den er sagt på engelsk af en dansker, i en form vi ikke kender, og at den siden, formodentlig lang tid efter udsigelsen, er blevet refereret på et tredje sprog, fransk. Følgende beskrivelse bygger derfor på en hypotetisk rekonstruktion, der dog er hjulpet lidt på vej af visse kommentarer fra den franske interviewpersons side. Han bemærkede således at han ikke kan tolke humor hos sine danske kolleger, fordi ${ }^{6}$

det bliver sagt med samme intonation. På fransk har vi masser af intonation, vi understreger med intonation når det er en joke. På den måde kan man se det kommer. På dansk kommer joken helt fladt ("platement") i diskussionen. Der er ikke nogen advarselssignaler ("signes avant-coureurs"). Først når det hele er sagt, må jeg tage mig tid til at overveje om det var en joke eller ej.

Jeg formoder at danskeren hvis han havde talt dansk i den beskrevne situation, ville have benyttet 'advarselssignaler' i form af de for dansk karakteristiske og på dansk hyppigt anvendte modalpartikler (ja, jo, vel, 
Humor og ironi ...

nok, vist, bare, hellere, osv.), der netop bruges som instrukser til at signalere en given form for indforståethed mellem afsender og modtager. For at en ironisk sproghandling skal lykkes må der netop være en sådan form for indforståethed, der advarer: 1) "det der kommer nu skal ikke tages alvorligt", dvs. ikke som en bona-fide sproghandling og 2) jeg refererer en andens synspunkt, som 3) jeg lægger afstand til, dvs. som en ironisk handling. I en identisk situation som den beskrevne er det sandsynligt at den danske afsender ville have formuleret sig på en måde som angivet nedenfor ${ }^{7}$ :

6. Så må du nok (hellere/bare) lade dig skille og gifte dig med en dansker $^{8}$

7. Så må du vel (hellere/bare) lade dig skille og gifte dig med en dansker

8. Så må du vist (hellere/bare) lade dig skille og gifte dig med en dansker

Og med det fulde udtræk:

9. Så må du jo nok/vel hellere bare lade dig skille og gifte dig med en dansker

Forskellige kombinationer af modalpartikler, hver især med deres specifikke kommunikative betydning, er mulige. Krylova (2007) taler om at "modalpartiklerne iscenesætter et kodet polyfonisk samspil" mellem 1., 2. og 3. persons stemmer (Krylova 2007:189), og hun behandler 'nok', 'vel' og 'vist' som "formodningsord" (Krylova 2007:185), der udtrykker "problematisk modalitet" (Krylova 2007183). Hvor 'så' i eksempel (6) - (9) ovenfor udtrykker følge eller konsekvens (af at der ikke er plads på danskholdet på aftenkurset), så udtrykker afsender ved at bruge 'nok' (som i (6)) "at han ikke har nogen viden om det reelle sagsforhold, men han kommer med sin egen hypotetiske konklusion om ytringens sandhed, og den bygger han på nogle almene regler: sådan er det fordi sådan plejer det at vare" (Krylova 2007:185). Krylovas beskrivelse er interessant også for fænomenet ironi, fordi den implicitte henvisning til en fælles forforståelse i form af 'at sådan plejer det at være' svarer til den form for 'echoing' der netop anses som et grundtræk i ironiske ytringer (Sperber \& Wilson 1995), her som ekko af den gængse holdning. Kontrasten mellem 'p': "det plejer at vare sådan at når man ikke kan lære et fremmedsprog ved at gå på sprogkursus, så 


\section{Lita Lundquist}

lader man sig skille og gifter sig med en der taler sproget" og en virkelighed hvor dette udsagn gælder er naturligvis så grel, at tolkning som ikke-bona-fide sproghandling hurtigt melder sig (for danskere i det mindste).

Hvad 'vel' (som i (7)) angår, så "signalerer afsender over for modtager at han ikke ved, om det propositionelle indhold er sandt, men han giver modtager sit forslag til en forklaring af den opståede situation" (Krylova 2007:186). Krylova citerer Davidsen-Nielsen for at have beskrevet 'vel' som antagende og bekraeftelsess $\phi g e n d e$ (DavidsenNielsen 1993). Ifølge Krylova er 'vel' "en andenpersonspartikel: "Ved hjælp af den involverer afsender modtager i vurderingen af udsagnets sandhed” (Krylova 2007). 'Vel' udtrykker således en så stærk appel til modtager om selv at tage stilling til og vurdere den citerede ytrings sandhedsværdi, at den afstandtagende, dvs. ironiske, tolkning ligger lige for.

Ved hjælp af 'vist' (som i (8)) "signalerer afsender over for modtager, at han ikke er sikker på, at det propositionelle indhold er sandt" (Krylova 2007:189). Krylova kalder det indirekte evidens, hvor afsender "forbliver i sin subjektive verden, fordi han på grund af manglende evidens fortolker det, han sanser i den objektive verden, efter sit eget skøn" (Krylova 2007:189). Dette subjektive skøn i forhold til det udsagte markerer som de andre formodningspartikler en distance til sandhedsværdien.

Ytringerne i (6) - (8) kunne også have indeholdt partiklerne 'bare', der udtrykker 'en let løsning' for modtager og/eller 'hellere', der udtrykker et godt råd, et foretrukket alternativ. Disse modalpartikler understreger yderligere kontrasten mellem 'det lette alternativ' - lade sig skille og gifte sig igen - og virkelighedens verden.

"Sammenlagt" som i (9) ${ }^{9}$ ville anvendelsen af disse formodningspartikler have været et stærkt signal til modtager om 1) at afsender gengiver en andens holdning, og 2) at afsender lægger afstand til denne holdning. Polyfonien i ytringens sæt af modalpartikler leder mod den ekstreme polyfoni i form af ironi, hvor et citeret eller refereret udsagn $p$ via den afstandtagende holdning skal tolkes som sin modsætning ikke$p$; eller i sproghandlingstermer, en bona fide ytring skal tolkes først som en ikke-bona-fide sproghandling og straks derefter som en bona-fidecum-humor handling.

Det er altså ikke rigtigt at danskere ikke anvender sproglige instrukser for at signalere ironi, men det er sandsynligt at vedkommende dansker ikke har kunnet overføre dem til det anvendte lingua franca, 
engelsk, ligesom det er sandsynligt at franskmanden - hvis han var blevet optaget på det famøse danskhold og havde lært dansk - ikke ville have opfattet disse advarselssignaler på dansk, da de pga. af deres sproglige kortfattethed og ubetonethed let går et fremmed øre forbi.

Det synes således at spille ind at dansk, som illustreret i (6) - (9) ovenfor, kan beskrives som et modtagerorienteret sprog "der anvender modtagerens stemme som sin grundstemme", som Per Durst-Andersen beskriver det inden for rammen af sin teori om sproglige supertyper (Durst-Andersen 2007; Durst-Andersen 2010). Alle sprog opererer ifølge Durst-Andersen med de tre grundstemmer, første, anden og tredje persons stemme, men hvert sprog vælger én af stemmerne som grundstemme. Heraf følger at "(n)år et sprog som dansk taler med modtagers stemme og derfor egentlig taler i informationer (den færdige sætning er således et signal til modtager om at finde den intenderede mening med ytringen), må modtager selv rekonstruere situationerne som afsender havde i sin erindring" (Durst-Andersen 2007:166).

Fransk ligger nærmere supertypen virkelighedsorienterede sprog (som fx russisk), hvor grundstemmen er virkelighedens stemme, og hvor ytringen opstiller en model af en konkret situation ${ }^{10}$. Selv om de to parter i den givne situation kommunikerede på et lingua franca ${ }^{11}$, synes de to samtaleparter i situationen at forblive i deres henholdsvis modtager- og virkelighedsorienterede sprogsystem. Den franske modtager har formodentlig foretaget og er blevet ved en virkelighedstolkning af det propositionelle indhold i den refererede ytring "Du må lade dig skille og gifte dig med en dansker", der i sandhed er en voldsom indgriben $i$ en persons virkelighed og privatliv. Franskmanden har med forankring i sin virkelighedssupersprogtype ikke forstået at "(o)ut-putstrukturen i dansk er versioneret til modtager så han selv kan gå videre for at finde situationerne bag de informationer som sproget har hjulpet ham med" (Durst-Andersen 2007:178).

Der er således sproglige forklaringer på hvorfor dansk ironi mislykkes som ikke bona-fide og bona-fide-cum-humor sproghandling overfor ikke dansk-sprogede, men dansk som modtagersprog og det store inventar af modalpartikler der står til danskerens rådighed er ikke tilstrækkeligt til at forklare hvorfor danskerne anvender ironi i så vid udstrækning, i både privat- og professionelt liv. En sammenligning mellem dansk og fransk kultur og identitet kan kaste lys over dette spørgsmål, men lad os først se hvordan ordspil i form af en danskers lapsus linguae i en fransk kontekst helt korrekt og med overvældende succes blev tolket som en ikke-bona-fide sproghandling. 


\section{Lita Lundquist}

3.2 Ordspil - i form af lapsus linguae - som vellykket bona-fide-cumhumor sproghandling på en fransk arbejdsplads

Både danske og franske interviewpersoner pegede på ordspil som værende en typisk form for fransk humor. Et konkret eksempel blev givet af en dansk kvinde der som 20-årig arbejdede i et fransk stormagasin (Bazar Hôtel de Ville), hvor hun solgte danske møbler. Hun fortalte episoden i disse ord:

jeg sku sætte priserne ned på mine møb.... altså danske møbler... og så kom der en og spurgte hvad jeg lavede, j'en ai marre, je monte la moitié des prix, et je baise les autres ${ }^{12}(. .$.$) Så gik der ikke to minutter, så kom der$ en ny og spurgte, qu'est-ce que tu fais, (...) og så der gik jo ik ti minutter så var der ti der var kommet og spørge om (...) og så fandt jeg ud af jeg sku altså ik baise dem jeg skulle diminuere dem (...) så var det jo ik morsomt (...)

Her har vi et nydeligt eksempel på en lapsus linguae der består i en minimal fonetisk fejl, idet personen (formodentlig i overkorrekthed) stemmer 's'et i \{beze\}, 'baiser' der betyder "kysse, elske (= have kønslig omgang med), gå i seng med, hore med, knalde, kneppe" (Blinkenberg og Høybye Fransk-Dansk Ordbog), hvor hun skulle have sagt og formodentlig mente 'baisser' \{bese\} (= sænke, sætte ned) med ustemt 's'. Det sproglige ordspil var således yderst økonomisk, men den humoristiske effekt enorm, idet mindst ti kolleger strømmede til for at høre hende gentage fejlen og tage del i den fælles latter. Hendes lapsus linguae fik en yderligere dimension da også chefen kom til, chefen som efter interviewpersonens udsagn netop lå i med flere af hendes kolleger blandt ekspeditricerne, hvilket blot understregede glæden ved at overskride det seksuelle tabu. Eksemplet illustrerer også at humor selv ubevidst humor - kan virke forløsende i en arbejdssituation, der inddrager flere sprog og flere kulturer, og at humor dermed kan virke som mediator, som skaber af "a social tie", "a momentary association" (Latour 2005:64-5) i tværsproglige og -kulturelle forhandlinger.

\subsubsection{Sproglig forklaring på ordspil i fransk}

Alle interviewpersonerne i undersøgelsen, franske som danske, understregede som nævnt - de førstnævnte med åbenlys glæde og entusiasme - ordspil som værende den foretrukne form for humor 
i Frankrig. En forklaring på præferencen for ordspil, der meget betegnende kaldes både "jeux de mots" og "mots d'esprit" på fransk, vil måske kunne finde en forklaring i det franske sprog, i dets fonetiske og prosodiske system (med syllabisk prosodi (Herslund 2003:72)), i dets ordforråd og orddannelsesmønster, evt. dets morfologi og syntaks. Et første forsøg på forklaring kunne findes i Saussures begreb "associative relationer" ("rapports associatifs" (Saussure 1983:175), hvor fx leksemet 'enseignement' (undervisning) beskrives som associerende via fire spor, i fire retninger, hvoraf ordspil først og fremmest associerer i de to sidste retninger:

1. via roden 'enseign' til 'enseigner', 'enseignons', etc.

2. via betydningsanalogi med 'apprentissage', 'éducation', etc.

3. via fælles suffiks med f.eks. 'changement', 'armement', etc.

4. via fælles lyd-billede ("image acoustique") med f.eks. 'clément', 'justement', etc.

En anden mulig forklaring kunne evt. findes i det danske og franske sprogs forskellige 'lydbilleder' - "sound shapes" (Jakobson \& Waugh 1979) - dvs. i modsætningerne i de to sprogs lydlige distinktive træk og i systematiske regelmæssigheder i homonymer og polysemer, anvendt i "punlike metathesis of distinctive features (which) may serve to weld together words etymologically unrelated but close in their sound and meaning" (Jakobson \& Waugh 1979:7). Jeg skal ikke forfølge disse spor her, men afrunde dette afsnit med et ordspil, sagt af en fransk vinbonde fra Alsace under et møde hvor man diskuterede om og hvordan man skulle omdøbe den kendte mousserende vin Crémant d'Alsace. Vinbonden modsatte sig hele foretagendet, idet han mente at vinen så bare ville blive kaldt Ex-Crémant ${ }^{13}$.

\section{Danmark - Frankrig: kulturelle forskelle}

Humor og ironi udtrykkes og tolkes i givne kontekster, i den konkrete kommunikationskontekst, som i denne unders $\varnothing$ gelse er en tværsproglig og tværkulturel arbejdssituation, og i en større kontekst hvor de kommunikerende parters specifikke baggrundsviden og kulturelle normer spiller ind. I sidstnævnte tilfælde taler man om en national kultur eller endog en national identitet eller national karakter, der er dannet og formet af forskellige civilisationsprocesser i de pågældende lande. Den tyske sociolog Norbert Elias (Elias 1969; Elias 1994; N. Elias \& Mennell 2006) har formuleret denne relation mellem nationers historiske 
udvikling og dannelsen af givne sociale relationer og adfærdsmønstre i disse ord:

The social units that we call nations differ widely in the personality structure of their members, in the schemata by which the emotional life of the individual is molded under the pressure of institutionalized tradition and of the present situation (Elias 1994:27) (mine fremhævelser).

Der er iøjnefaldende forskelle mellem civilisationsprocesserne i Frankrig og Danmark, der på nuværende tidspunkt i udviklingen har formet henholdsvis et hierarkisk og et horisontalt ordnet samfund. Frankrig er skabt 'ovenfra' fra hofsamfundet - tydeligst eksemplificeret i solkongens hof i det 17. århundrede. Elias beskriver således den franske civilisationsproces som en

direct continuation of the courtly-aristocratic tradition of the seventeenth century (...) When the bourgeoisie became a nation, much of what had originally been the specific and distinctive social character of the courtly aristocracy and also of the courtlybourgeois groups, became, in an ever-widening movement and doubtless with some modification, the national character. (Elias 1994:30).

Et sådant aristokratisk hofsamfund giver sig udslag i specielle sociale relationer, i en speciel "courtly rationality" (Elias 1994:47), der bygger på en stadig beskyttelse og markering af egen plads i hierarkiet:

the necessity to distinguish oneself from others and to fight for opportunities with relatively peaceful means, through intrigue and diplomacy, enforced a constraint on the affects, a self-discipline and self-control, a peculiarly courtly rationality (Elias 1994:268; mine fremhævelser).

Denne hoflogik afføder en høflig - i ordets egentlige betydning - omgangs- og konversationsform ${ }^{14}$, der efterhånden, med Elias' ord, er sivet ned i det franske samfund og har dannet en national karakter:

Stylistic conventions, the forms of social intercourse, conversation, articulateness of language and much else - all this is first 


\section{Humor og ironi ...}

formed in France within courtly society, then slowly changes, in a continuous diffusion, from a social into a national character." (Elias 1994:30) (mine fremhævelser).

Den danske civilisationsproces er vidt forskellig. De fleste historiske og sociologiske behandlinger starter med nederlaget i 1864, hvor Danmark gik fra at være en stor til at være en lille nation (Østergaard 2006), og lægger vægt på Danmarks udvikling nedenfra fra en folkelig bondekultur til et egalitært og lineært korporatisme- og konsensussamfund (Kaspersen 2006; Kaspersen 2008).

Den forskellige anvendelse og fortolkning af humor og ironi i Frankrig og Danmark får yderligere forklaring via disse forskelle i national karakter. I et hierarkisk samfund, som det franske, vil folk være mere tilbøjelige til at beskytte og "paradere" (Elias) deres sociale status og adskille sig fra andre ved elegant konversation og omgangsform. Ordspil udgør en raffineret sprogbrug, der viser afsenderens stilistiske overlegenhed, og hvis mål er sproget selv (3. person), mens ironi rettet mod 2. person indebærer en risiko for at blive taget for bonafide pålydende og vise tegn på manglende selvkontrol. I et hierarkisk samfund er i særdeleshed selvironi faretruende for den sociale status, idet den nedvurderende selvfremstilling ("self-depreciating humor" (Raskin 1985)) risikerer at blive taget for pålydende. Selvironi forklares lettere i en horisontal, egalitær social ordning, hvor den ikke er truende for selvværdet, men tværtimod finder en naturlig plads $i$ et socialt fællesskab hvor ingen hæver sig - må eller tør hæve sig - over de andre. Hvor Janteloven repræsenterer den negative side af denne lighedskultur, har andre formuleret anvendelsen af ironi og selvironi i mere positive vendinger. Det gælder Fogh Kirkeby, der siger:

Virtuelt slår ironien et socialt fællesskab an, der som et uartikuleret communitas ligger mellem de talende (Kirkeby 2003),

og det gælder selvironi hos Steven Pinker:

One way to signal to a companion that the basis for a relationship is friendship rather than dominance is to call attention to an undignified trait in yourself or in the companion, disavowing the possibility that one of you has something to lord over the other (Pinker 2007:408). 


\section{Lita Lundquist}

Pinker berører her den sociologiske relation i anvendelsen af humor og specielt ironi, der i humorteorier betegnes som 'overlegenhedsteorier' ("superiority" eller "hostility" theories), der går tilbage til Platon, Aristoteles og Hobbes (se mere (Attardo 1994:49)). Eksempel 5 ovenfor på misforstået ironi viste at anvendelsen blev opfattet af franskmanden som en aggressiv, ekskluderende sproghandling, og ikke - som formodentlig intenderet af den danske afsender - som en "cohesive", inkluderende handling (Attardo 1994:50).

\section{Danmark - Frankrig: ledelsesmæssige og arbejdsorganisatoriske forskelle}

De kulturelle nationale forskelle præger også arbejdssituationer, som beskrevet inden for ledelsesteorier der behandler nationale forskelle i arbejds- og ledelseskulturer (Crozier 1997; Crozier \& Tilliette 2000; P. d'Iribarne 1998; P. d'Iribarne 1994; Hofstede 1984; Lubatkin, Lane, Collin, \& Very 2005; Schramm-Nielsen 2001; Schramm-Nielsen 1993). D’Iribarne (1994) betegner således arbejds- og ledelseskultur i Frankrig som værende præget af en æreslogik ("la logique de l'honneur"), hvormed menes ære over at have en given professional status og tilhøre en given profession. I sin sammenligning af fransk ledelseskultur med den hollandske og den amerikanske, understreger d'Iribarne franskmændenes hierarkiske ledelsesstruktur over for hollændernes konsensus- og amerikanernes kontraktkultur. Den hierarkiske top-down styrede ledelsesstruktur, der i de nævnte værker fremstilles som værende alment gældende på franske arbejdspladser, sammenlignet med den flade, konsensuss øgende på for eksempel danske arbejdspladser (Schramm-Nielsen 1993; Schramm-Nielsen 2001), bidrager til at forklare hvorfor humor i form af ironi og selvironi er en mere udbredt social kommunikationsnorm på de danske end på de franske arbejdspladser. Dette fremgår også af flere bemærkninger fra de interviewede personer. En dansk interviewperson siger:

danskerne de har måske en slags, 'falsk... beskedenhed (...) danskerne ja, hvorimod franskmændene er ikke bange for at føre sig frem $(. .$.

I Frankrig derimod højner man ifølge en af de franske interviewpersoner hellere sin status:

I Frankrig elsker vi at vise os selv i det bedste lys, det virker overhovedet ikke i Danmark. Situationen er altså lige modsat. 
Humor og ironi ...

Danskerne har tendens til sætte personen foran sig i en lavere position, fordi man ikke kan sætte sig selv i en højere position (...) I Frankrig elsker vi at højne vores position, det er virkelig del af kulturen, og ingen tager det alvorligt. ${ }^{15}$

Hvor det således synes at være et faktum at humor og (selv)ironi er en accepteret social omgangsform på danske arbejdspladser, er det bemærkelsesværdigt at sådanne ikke-bona-fide og bona-fide-cum-humor sproghandlinger oven i købet direkte anbefales som ledelsesinstrument i danske ledelsesteorier og erhvervspsykologi. Fogh Kirkeby nævner således i sin behandling af "tillid som styringsparameter i erhvervsøkonomisk sammenhæng" (Kirkeby 2003:25) humor og ironi som to af de fire "kommunikative modi" ${ }^{16}$ (Kirkeby 2003:25) der bidrager til skabelsen af tillid. Jan Molin nævner selvironi som en "refleksiv ledelsespraksis", der "potentielt kan destruere det selvhøjtidelige" (Molin 2006:31), fordi der i den selvironiske eksponering af en selv "opstår en mulig gensidighed, der bygger på anerkendelse af det fælles forpligtende samvær" (Molin 2006:32). Begreberne 'gensidighed' og 'anerkendelse af det fælles', her brugt i en erhvervspsykologisk kontekst, viser med begrebet "et uartikuleret communitas der ligger mellem de talende" interessante anknytningsmuligheder til det ovenfor nævnte karakteristiske træk ved det danske sprog som værende et modtagerorienteret sprog (se 3.1.2).

\section{Konklusion og perspektiver}

I undersøgelsen og beskrivelsen af hvordan humor og ironi skal tolkes fra at være en ikke-bona-fide sproghandling til at være en bona-fidecum-humor sproghandling for at være vellykkede sproghandlinger, har det vist sig at forskelle mellem danskeres og franskmænds tolkning af humor og ironi kan forklares ved såvel sproglige som nationalkulturelle faktorer. Dansk som modtagerorienteret sprog, bl.a. udtrykt i dets mange formodningspartikler, kolliderer med fortolkningsprocessen hos den franske modtager, der via fransk er kodet med et virkelighedsorienteret sprog, et sprogtypologisk clash, der yderligere forstærkes af mellemkomsten af engelsk som lingua franca. Forskelle i nationale karaktertræk og ledelses- og arbejdskulturer forstærker den kontekstuelle faktor i fortolkningsprocessen, et faktum både danskere og franskmænd - og alle andre der agerer i interkulturelle kontekster - skal være opmærksomme på, for at undgå at humor fra at være en positiv sociologisk mediator bliver en negativ sociologisk overlegenheds- og magtfaktor. 


\section{Lita Lundquist}

\section{Noter}

1 Det skal understreges at sandhedskravet gælder den indlejrede proposition og ikke sproghandlingen som sådan.

2 Samt til en vis grad engelsk som lingua franca.

3 Cf. Freuds "forestillingsverdener".

4 "L'ironie n'est pas superdrôle", som en fransk interviewperson bemærkede.

5 Oversat fra fransk.

6 Følgende er oversat så vidt muligt ord for ord fra fransk.

7 Da disse modalpartikler er tæt på umulige at oversætte til andre sprog, inklusive engelsk der blev anvendt som lingua franca i den givne situation, med andet end længere parafraser, er det højst sandsynligt at der ikke har været lignende instrukser i den engelske ytring.

8 I den franske interviewpersons gengivelse anvendes leksemet "Danoise", der udover at være markeret for femininum også indeholder visse konnotationer i retning af "høj, blond, skandinavisk kvindetype".

9 Her er også tilføjet 'jo', der er "en affirmativ modtagerorienteret modalitet, som bruges af afsender til at bekræfte enten det propositionelle indholds sandhed eller dets sandsynlighedsgrad over for modtager" (Krylova 2007:184). Eksempel (9) viser at den kumulative effekt af flere modalpartikler ikke gør afkodningen for en udlænding og dennes chance for at nå over den rette ikke bona-fide til en bona-fide-cum-humor tolkning lettere.

10 Den tredje supertype er afsenderorienterede sprog (som fx bulgarsk).

11 Engelsk, som også er et modtagerorienteret sprog, men med andre "hovedstemmer" og "bistemmer" end dansk; se Durst-Andersen (2007) for en detaljeret beskrivelse.

12 "Jeg er dødtræt af det, jeg hæver halvdelen af priserne, og knepper de andre".

13 Georges Kleiber, personlig kommunikation.

14 Med specielle former for face saving høflighedsstrategier (Brown \& Levinson 1987).

15 Oversat ord for ord fra fransk.

16 De to andre kommunikative modi er alvor og retfærdig harme. 
Humor og ironi ...

\section{Litteratur}

Attardo, S. (1994). Linguistic theories of humor, Mouton de Gruyter.

Brown, P. \& S.C. Levinson (1987). Politeness: Some Universals in Language Usage, Cambridge University Press.

Crozier, M. (1997). Etat modeste, état moderne. Stratégie pour un autre changement (3.éd ed.), Fayard.

Crozier, M. \& B. Tilliette (2000). Quand la France s'ouvrira..., Fayard.

Davidsen-Nielsen, N. (1993). Det er sgu da nu vist en misforståelse: Om nogle svære småord på dansk, i Nyt fra Sprognaevnet, 3. København :1-9.

d'Iribarne, P. (1998). Cultures et mondialisation. Gérer par-delà les frontières, Seuil.

d'Iribarne, P. (1994). The honour principles in the «bureaucratic phenomenon», i Organization studies, vol. 15:81-97.

Durst-Andersen, P. (2007). Det danske sprogs mange stemmer, i R. Therkelsen (red.), Sproglig polyfoni. tekster om Bachtin og ScaPoLine, Århus Universitetsforlag:163-180.

Durst-Andersen, P., (2010). Language, Cognition and Mentality, i P. Durst-Andersen \& E. F. Lange (ed.) Mentality and Thought. North, South, East and West, Copenhagen Business School Press: 29-50.

Elias, N. (1969). Über den prozess der zivilisation: Soziogenetische und psychogenetische untersuchungen (Aufl. Bd 1-2 ed.), Francke.

Elias, N. (1994). The civilizing process. History of manners, state formation and civilization, Basil Blackwell.

Elias, N., \& S. Mennell (2006). The Court society (Revised ed.), University College Dublin Press.

Fauconnier, G. (1994). Mental spaces aspects of meaning construction in natural language, Cambridge University Press.

Fauconnier, G. (1999). Mappings in thought and language (Reprint ed.), Cambridge University Press.

Freud, S. (1981). Der Witz und seine Beziehung zum Unbewussten, Fischer Taschenbuch Verlag.

Freud, S. (1994). Vitsen og dens forhold til det ubevisste, Norsk utgave. Pax.

Grice, P. (1967). Logic and conversation, University of California. 
Guiraud, P. (1976). Les jeux de mots, Que sais-je?

Habermas, J. (1976). Was heißt Universalpragmatik? In: Vorstudien und Ergänzungen zur Theorie des kommunikativen Handelns (1984):353-440.

Herslund, M. (2003). Essence du langage, types linguistiques et systèmes métriques, i Language and Culture. Copenhagen Studies in Language, 29:71-82.

Hofstede, G. (1984). Culture's consequences. International differences in work-related values (abr ed.), Sage.

Jakobson, R. \& L. Waugh (1979). The Sound Shape of Language, Harvester Press.

Kaspersen, L. B. (2006). The formation and development of the welfare state, i National identity and the varieties of capitalism. the Danish experience, McGill-Queen's University Press:99-132.

Kaspersen, L. B. (2008). Danmark $i$ verden, Hans Reitzels Forlag.

Kirkeby, O. F. (2003). Er tillid en tilbøjelighed? Om fænomenet tillid set i forhold til begreberne alvor, ironi, humor og retfærdig harme, i Erhvervspsykologi, 1(1):24-34.

Krylova, E. (2007). Epistemisk polyfoni på dansk, i R. Therkelsen (red.), Sproglig polyfoni. tekster om Bachtin og ScaPoLine, Aarhus Universitetsforlag:181-203.

Latour, B. (2005). Reassembling the social. An introduction to actornetwork-theory, Oxford University Press.

Lubatkin, M.H., P.J. Lane, S. Collin \& P. Very (2005). Origins of corporate governance in the USA, Sweden and France, i Organization Studies, Vol. 26 (No. 6):867-888.

Lundquist, L. (1982). Virkelighed, fiktion og realisme, set gennem sprogbehandlingsteorien, i S. Jansen et al. Tekst og Virkelighed, Akademisk forlag:63-70.

Lundquist, L. (2009). Humour as a mediator in cross-cultural professional settings. Examples from Danish and French. CBP Working Papers, 66.

Molin, J. (2006). Selvironi som ledelseskompetence, i Erhvervspsyko$\log i, 4(1): 26-45$.

Raskin, V. (1985). Semantic mechanisms of humor, Reidel.

Ricoeur, P. (1978). The rule of metaphor: Multi-disciplinary studies of the creation of meaning in language [La métaphore vive.], Routledge \& Kegan Paul.

Saussure, F. d. (1983). Cours de linguistique générale. Paris. 
Humor og ironi ...

Schramm-Nielsen, J. (2001). Cultural dimensions of decision making: Denmark and France compared, i Journal of Managerial Psychology, 16 (6):404-423.

Schramm-Nielsen, J. (1993). Dansk-fransk samarbejde i erhvervsvirksomheder, Samfundslitteratur.

Searle, J. R. (1977). Speech acts: An essay in the philosophy of language, Cambridge University Press.

Searle, J. R. (1979). Expression and Meaning. Studies in the Theory of Speech Acts, Cambridge University Press.

Sperber, D., \& Wilson, D. (1995). Relevance. Communication and Cognition (2nd ed.), Blackwell.

Lita Lundquist

Professor ved International Center for Business and Politics

Copenhagen Business School

Porcelænshaven 22, 2000 Frederiksberg

11.cbp@cbs.dk

www.cbs.dk/staff/ll 